\title{
Proximity to rocky reefs alters the balance between positive and negative effects on seagrass fauna
}

\author{
Fernando Tuya ${ }^{1,2,6, *}$, Mathew A. Vanderklift ${ }^{3}$, G. A. Hyndes ${ }^{2}$, T. Wernberg ${ }^{2,4}$, \\ M. S. Thomsen ${ }^{2,5}$, C. Hanson ${ }^{2}$ \\ ${ }^{1}$ CIIMAR, Rúa das Bragas 287, Porto, Portugal \\ ${ }^{2}$ Centre for Marine Ecosystem Research, Edith Cowan University, Joondalup Drive, 6027 Western Australia, Australia \\ ${ }^{3}$ CSIRO Marine and Atmospheric Research, Private Bag 5, Wembley, 6913 Western Australia, Australia \\ ${ }^{4}$ School of Plant Biology, University of Western Australia, Hackett Drive, Crawley, 6009 Western Australia, Australia \\ ${ }^{5}$ Department of Marine Ecology, National Environmental Research Institution, PO Box 358, 400 Roskilde, Denmark
}

${ }^{6}$ Present address: BIOGES, 35017 University of Las Palmas de GC, Canary Islands, Spain

\begin{abstract}
Proximity to habitat margins can alter the balance between positive and negative forces on species abundance. Based on this idea we examined abundance patterns of herbivorous gastropods in seagrasses adjacent to rocky reefs. We tested whether the balance between the intensity of predation (negative effect) and recruitment of new individuals (positive effect) changes with increasing distance from reefs. Abundances of gastropods varied with distance to reefs, but the direction of changes in abundance was taxon-specific: some taxa decreased in abundance with increasing distance from reefs (e.g. Pyrene bidentata), while others showed the opposite pattern (e.g. Cantharidus lepidus). Predators were more abundant on reefs and in immediately adjacent seagrasses, relative to seagrass meadow interiors. Predation intensity on 2 species with opposite patterns of abundance with proximity to reefs ( $P$. bidentata and $C$. lepidus) was consistently higher in seagrasses near reef edges than in seagrass interiors, and $C$. lepidus was more susceptible to predation than $P$. bidentata. Recruitment of $P$. bidentata was higher in seagrasses adjacent to reefs relative to seagrass interiors, whereas recruitment of $C$. lepidus did not vary with distance from reefs. Dispersal of $P$. bidentata individuals from reefs probably explains the greater recruitment of $P$. bidentata at seagrass edges relative to interiors; this compensates for losses due to predation, thereby enabling high abundance in seagrasses adjacent to reefs despite suffering greater predation at this distance relative to the interiors of the seagrass meadows. In contrast, losses of $C$. lepidus due to predation reduced its abundance in seagrasses adjacent to reefs, while recruitment was invariant, so this species was most abundant in seagrass meadow interiors. Thus, proximity to habitat margins affected abundance patterns by influencing mortality (predation) and replenishment (recruitment) of populations. This balance was dependent on species identity, and led to contrasting patterns of abundance among species with proximity to habitat interfaces.
\end{abstract}

KEY WORDS: Cross-habitat exchanges · Gastropods $\cdot$ Habitat connectivity $\cdot$ Predation $\cdot$ Supply-side processes $\cdot$ Edge effects $\cdot$ Habitat linkages $\cdot$ Rocky reefs

\section{INTRODUCTION}

A major focus in ecology is to predict how different processes act simultaneously to determine the abundance and distribution of species. Understanding the balance between processes that enhance growth or add new individuals ('bottom-up' and 'supply-side' processes) and those that limit growth or cause mortality ('top-down' processes) is particularly important (Menge 2000). Studies of the relative balance between these forces have mostly been restricted to single, relatively uniform habitats. Habitats are, however, usually connected within landscapes, and the balance between positive and negative forces on abundances 
of species may vary where distinct habitats are spatially linked, such as at edges (Kareiva \& Wennergren 1995).

Edges between juxtaposed habitats can influence the type and intensity of interactions between species and thus affect ecological patterns (Cadenasso et al. 2003). The movement of organisms from one habitat to another is an important ecological process because it can lead to differences in the abundance of an organism between habitat margins and interiors. For example, incursions of predators from their shelters into surrounding habitats can diminish prey abundances near habitat margins (e.g. Bell et al. 1991, Eggleston et al. 1999, Fagan et al. 1999, Langlois et al. 2005, Galvan et al. 2008), while cross-edge movements of individuals, especially propagules, can increase abundances (Pulliam 1988).

When rates of these processes vary with proximity to habitat edges, prey species may vary in abundance accordingly (e.g. Langlois et al. 2005). Responses can also vary with the characteristics of the habitat. For example, vulnerability to predation can vary with the architecture of the dominant habitat (Heck \& Crowder 1991, Fagan et al. 1999, Rand et al. 2006), which is illustrated by the superiority of forests to open habitats in providing protection for small birds against predators (Rodriguez et al. 2001). Further, species with different traits, such as vulnerability to predation or ability to disperse, can show contrasting responses to key processes. For example, differences in the morphological traits (e.g. thickness) of mollusc shells can affect their predator's handling time and ability to consume prey (Quensen \& Woodruff 1997, Seitz et al. 2001). Each of these influences (proximity to edge, habitat architecture, and species traits) can interact to change the relative influence of positive and negative forces on abundance.

Seagrasses are key habitats along temperate and tropical coasts of the world (Hemminga \& Duarte 2000), where they are frequently distributed as mosaics interspersed with other habitats, such as rocky reefs, coral reefs, mangroves and unvegetated sediments. In particular, reef-seagrass landscapes are common elements of temperate (e.g. Australasia, Wernberg et al. 2006) and tropical latitudes (e.g. the Caribbean region and Florida, Valentine et al. 2008; the Indo-Pacific region, Dorenbosch et al. 2005). In these systems, many trophic interactions occur across 2 or more habitats. For example, predation on epifauna may be most intense in seagrasses adjacent to reefs, as a result of the foraging of reef-associated consumers (Valentine et al. 2008). Seagrass meadows may also be recipients of materials advected from reefs (e.g. propagules, nutrients, detached vegetation). These flows strongly affect both ecological and abiotic pro- cesses in seagrass meadows. For example, movement of propagules leads to high diversity and biomass of epiphytic algae on seagrasses near reefs (Van Elven et al. 2004), and the accumulation of detached reef algae influences food webs in seagrass meadows (Wernberg et al. 2006).

We tested whether proximity to reefs influences the abundance patterns of herbivorous gastropods ( $<25 \mathrm{~mm}$ total body whorl) in seagrass meadows by affecting the intensity of, and balance between, 'topdown' (predation) and 'supply-side' (recruitment) processes. Specifically, we predicted that (1) abundance of gastropods changes with proximity to rocky reefs, (2) predation by reef-associated consumers (fishes and decapod crustaceans) is highest in seagrasses adjacent to reefs and (3) proximity to reefs can affect the supply of new individuals. Because rates of ecological processes in seagrass systems can be strongly influenced by the architecture of the seagrass (Heck \& Orth 2006), we determined the effect of 2 seagrasses with contrasting physiognomy (Posidonia versus Amphibolis) on these patterns and processes as well as whether patterns were spatially consistent between 2 different locations. This study was then based on surveys and experiments designed to test a set of specific hypotheses that involves both effects of individual factors (how patterns and processes change with proximity to reefs) and interactions (e.g. whether patterns and processes at different proximity to reefs were consistent between 2 seagrass species of contrasting physiognomy), as well as random effects across space (to test for generality of effects across 2 locations and among multiple reefs within each location). Hypotheses were tested with generalized linear models, in particular orthogonal mixed-effects ANOVA (Underwood 1997) that partitions the variability associated with each of the experimental factors (e.g. distance, seagrass types).

Gastropods are appropriate model species since they are an important part of the diet of predators (Edgar 1990a,b, MacArthur \& Hyndes 2007), and food limitation is not a major factor influencing the patterns of distribution of these grazers due to the abundance of food in these systems, e.g. epiphytes and peryphyton (Jernakoff \& Nielsen 1998).

\section{MATERIALS AND METHODS}

Study area. The study was carried out on rocky reefs and in adjoining seagrass meadows at 2 locations $\sim 250 \mathrm{~km}$ apart in southwestern Australia: Marmion $\left(31^{\circ} 50^{\prime} \mathrm{S}\right)$ and Jurien Bay $\left(30^{\circ} 18^{\prime} \mathrm{S}\right)$. In this area, the coast is characterized by sequences of limestone reefs parallel to the shore at distances ranging from $<1$ to $10 \mathrm{~km}$ offshore. Seagrass meadows consisting of Posi- 
donia spp. and Amphibolis spp. are interspersed among these reefs along more than $1500 \mathrm{~km}$ of coastline. We selected 6 reefs, each separated by $>400 \mathrm{~m}$, within each location: 3 adjacent to meadows dominated by Posidonia (predominantly $P$. sinuosa) and 3 adjacent to Amphibolis (principally A. griffithii) (Fig. S1 in the supplement at www.int-res.com/articles/ suppl/m405p175_app.pdf). Reefs adjacent to either Posidonia or Amphibolis meadows were, in all cases, interspersed at each location, i.e. reefs adjacent to either Posidonia or Amphibolis were not clumped within a particular area of each location, and were selected after our previous work in the study area (Wernberg et al. 2006, Vanderklift et al. 2007). In the study area, reefs are predominantly covered by macroalgae, primarily the small $(<1.5 \mathrm{~m})$, canopy-forming kelp Ecklonia radiata, and frondose fucalean algae, mostly of the genera Sargassum and Scytothalia. Patches of small (generally $<25 \mathrm{~cm}$ ) foliose red algae are interspersed between the larger stands of canopyforming algae (see Wernberg et al. 2003 for a detailed description of floral assemblages). All reefs had similar vertical relief. Depths of the seagrass meadows ranged between 2 and $6 \mathrm{~m}$ immediately adjacent to reefs, and between 3 and $9 \mathrm{~m}$ at the farthest distances from the reefs. All surveyed reefs were $<1 \mathrm{~km}$ from the adjacent shore of the nearest island (Fig. S1).

The strap-like leaves of Posidonia are generally uniform from base to tip, while Amphibolis has erect stems with small leaves arranged in terminal clusters, forming a denser canopy. Shoot densities for Posidonia tend to be higher than those of Amphibolis, while aboveground biomass (including epiphytes) is higher for Amphibolis (Jernakoff \& Nielsen 1998).

Abundance of gastropods. At each of the 12 selected reef-seagrass landscapes, a SCUBA diver handpicked all aboveground vegetation within 5 replicate $25 \times 25 \mathrm{~cm}$ quadrats haphazardly laid out at 5 distances relative to the reef-seagrass edge: on the reef itself, at $0 \mathrm{~m}$ (first seagrass patch immediately adjacent to the reef) and 10, 50 and $>300 \mathrm{~m}$ (first seagrass patch beyond the $300 \mathrm{~m}$ mark) distance away from the reef (Fig. S2 in the supplement). On reefs, collections were from haphazardly selected patches of red macroalgae, which typically host large densities of gastropods in the study area (for further details see Tuya et al. 2008). In seagrass meadows, samples were collected from monospecific stands. Each sample was washed in fresh water, and passed through a $1 \mathrm{~mm}$ mesh sieve. Vegetation was dried for $24 \mathrm{~h}$ at $70^{\circ} \mathrm{C}$ and then weighed (grams); the number and biomass of leaf clusters and stems, as well as the biomass of large epiphytes, was previously counted for Amphibolis spp. samples. These structural elements are the most relevant factors accounting for the spatial abundance patterns of sea- grass-inhabiting gastropods in the study area (Jernakoff \& Nielsen 1998), though a wide range of seagrass structural elements can affect the magnitude of ecological effects within seagrass meadows, such as predation intensity (Heck \& Crowder 1991). All gastropod individuals were identified to the lowest possible taxonomic level. Surveys were repeated twice on each reef, once each during the austral summer/autumn of 2006 and 2007, to determine whether patterns were consistent when measured at different times. ANCOVA was used to partition variation in the abundance (per quadrat, i.e. $625 \mathrm{~cm}^{2}$ ) of each of the 8 most abundant taxa (which accounted for $>90 \%$ of all individuals), separately for each survey (Fig. S3 in the supplement shows a schematic representation of the design); vegetation biomass (dry weight per quadrat) was included as a covariate to adjust (i.e. control) for differences in the amount of vegetation among samples. Each ANCOVA model incorporated the factors: (1) 'Location' (random factor), (2) 'Seagrass' (fixed factor and orthogonal to 'Location'), (3) 'Reef' (random factor nested within 'Location $\times$ Seagrass') and (4) 'Distance' (fixed factor orthogonal to all previous factors). In all cases, data were $\ln (x+1)$ transformed to stabilize variances. Heteroscedasticity, however, remained after transformation in almost all cases (Cochran's C-test, $\mathrm{p}<0.05$ ), and so statistical significance was conservatively set at $\alpha=0.01$. Pairwise Student-Newman-Keuls (SNK) tests were used to resolve differences in abundance among distances for each taxon. Potential differences in the biomass of each seagrass, as well as in the number of clusters and stems of Amphibolis spp., with varying proximity to reefs were tested for each survey by a 3-way ANOVA. The model incorporated the factors 'Location' (random factor), 'Reef' (random factor nested within 'Location') and 'Distance' (fixed factor orthogonal to the previous factors). The broad approach follows that used in other studies of connectivity between adjacent subtidal habitats (e.g. Langlois et al. 2005, Valentine et al. 2008, Vanderklift et al. 2007), and calculations of F-ratios in all cases followed Underwood (1997).

Abundance of predators. Potential predators (fish, octopus and decapod crustaceans, mainly the western rock lobster Panulirus cygnus) were censused on each reef during daytime hours in austral summer/autumn 2007. Fish were also counted in adjacent seagrass meadows at 2 distances relative to the reef-seagrass edge: 50 and $>300 \mathrm{~m}$ (P. cygnus is nocturnal and was not present in seagrasses during the day). Abundances were recorded by a SCUBA diver within three $25 \times 4 \mathrm{~m}$ transects $\left(100 \mathrm{~m}^{2}\right)$ oriented parallel to the edge of the reefs, with one side in contact with the adjacent seagrass meadow in the case of reef censuses. Patterns of abundance of predatory fish (all known and suspected 
predators of gastropods, Table S1 in the supplement) and the 5 most abundant fish species (those accounting for $>85 \%$ of all individuals) were examined with ANOVA (same model and transformations as outlined before for the abundance of the most abundant gastropod taxa) and SNK tests were used to resolve differences in abundance among distances.

Predation on gastropods in seagrasses. The relative intensity of predation was assessed by measuring the survival of tethered adults of 2 species of gastropods: Pyrene bidentata (9 to $15 \mathrm{~mm}$ ) and Cantharidus lepidus ( 7 to $12 \mathrm{~mm}$ total body whorl) (Fig. S4 in the supplement). We selected these 2 species because both are consumed by rock lobsters (Edgar 1990a,b) and fishes (MacArthur \& Hyndes 2007), and each displayed a opposite pattern of abundance with proximity to reefs (see Results). Although tethering can increase mortality rates, such experiments can still be used to compare relative mortality rates among different animals, or treatments, as long as the tether bias is constant among groups to be compared (see Peterson \& Black 1994 for a review). Artifacts as a result of tethering were probably minimized because (1) tethers were sufficiently long ( 50 to $60 \mathrm{~cm})$ to allow individuals to move and shelter within the seagrass canopy, and (2) laboratory tests (5 individuals of each species in five $15 \times 10 \times 7 \mathrm{~cm}$ aquaria) yielded no mortality and no escapes from tethers after $7 \mathrm{~d}$. Gastropods were tethered with a loop of monofilament line attached to the shell with cyanoacrylate glue (Fig. S4). The other end of the line was attached to a metal stake hammered into the substrate. Five individuals of each species were deployed in seagrasses 0 and $>300 \mathrm{~m}$ away from each of 8 reefs, with 2 reefs within each location adjacent to Amphibolis and Posidonia meadows. Tethers (between 20 and $30 \mathrm{~cm}$ apart) were retrieved after $5 \mathrm{~d}$ (the duration was selected based on pilot and similar studies) and the gastropods scored as alive or consumed; based on the results of the laboratory experiments, empty 'loops' were taken as evidence of predation. Differences in consumption between species among locations, distances, seagrasses and reefs were analyzed with multiple logistic regression. We were most interested in testing whether coefficients for each of the factors, and interactions between factors, were significant, so we focused on the significance of the deviances using a $\chi^{2}$ test (Hosmer \& Lemeshow 2000).

Prey selectivity by rock lobsters. We tested for differences in consumption of Pyrene bidentata and Cantharidus lepidus by rock lobsters (46 to $78 \mathrm{~mm}$ carapace length), by multi-choice experiments in indoor aquaria $(60 \times 40 \times 40 \mathrm{~cm})$ supplied with running seawater. Six rock lobsters (1 per aquarium) were offered 10 adult individuals (10 to $16 \mathrm{~mm}$ of total body whorl) of each gastropod species after $48 \mathrm{~h}$ of starvation. All aquaria lacked any structure where prey could shelter. We recorded consumption after another $48 \mathrm{~h}$, and differences in survival of the 2 species of gastropods and consumption rates of individual rock lobsters were tested with logistic regression.

Recruitment patterns of gastropods in seagrasses. Artificial seaweed units (ASUs, $165 \mathrm{~cm}^{3}$ of volume; Fig. S5 in our supplement, Rule \& Smith 2007) were used to test whether proximity to reefs ( 0 versus $>300 \mathrm{~m}$ ) altered the recruitment patterns of gastropods in seagrass meadows. We selected 4 reefs (a subset of those reefs where gastropod collections took place) in Marmion, with 2 reefs adjacent to Amphibolis and 2 reefs adjacent Posidonia meadows. Two ASUs were attached to each of 3 metal stakes 5 to $10 \mathrm{~cm}$ above the bottom for each distance; this height was chosen as a compromise between deploying the collectors within the seagrass canopy and minimising the influence of sediments, which we were unable to quantify. ASUs were collected after 4 wk in June 2007 by sealing them in separate resealable plastic bags. This is the period when recruitment of many species of molluscs, including Pyrene bidentata and Cantharidus lepidus, occurs in the study region (Edgar 1990a). In the laboratory, each collector was washed over a sieve with $0.5 \mathrm{~mm}$ mesh in fresh water. All gastropods were identified, counted and measured (total body whorl) to the nearest millimeter. We analyzed 5 ASUs per distance to maintain a balanced design (some ASUs were lost). Patterns of recruit abundance were examined using 3-way ANOVA, incorporating the factors: 'Seagrass' (fixed factor), 'Reef' (random factor nested within 'Seagrass') and 'Distance' (fixed factor orthogonal to the previous factors). Data were $\ln (x+1)$ transformed.

\section{RESULTS}

\section{Distribution of gastropods}

For most gastropod species, abundance increased with vegetation biomass (Tables $1 \& 2$ ), particularly for the most abundant taxa (e.g. Pyrene bidentata and Phasianella spp.). We observed contrasting patterns of abundance among taxa of herbivorous gastropods in seagrass meadows with varying proximity to reefs. Some taxa decreased in abundance with increasing distance from reefs (Pyrene bidentata, Fig. 1A; Phasianella spp., Fig. 1B); the magnitude, but not the direction, of these differences varied from reef to reef ('Reef [Location $\times$ Seagrass] $\times$ Distance', $\mathrm{p}<0.01$; Tables 1 \& 2). For these 2 taxa, abundances were higher in seagrasses immediately adjacent to reefs $(0 \mathrm{~m})$ relative to seagrass interiors (>300 $\mathrm{m}$ away from 
reefs) for 18 and 16 of the 24 possible pairwise comparisons (i.e. 12 reefs $\times 2$ times), respectively. Abundance in seagrasses $10 \mathrm{~m}$ away from reefs was higher than at $>300 \mathrm{~m}$ for 15 and 13 of the 24 pairwise comparisons, respectively for $P$. bidentata and Phasianella spp. Patterns in abundance of Phasianella spp. with distance varied between seagrasses in the second survey ('Seagrass $\times$ Distance', $\mathrm{p}<0.01$; Table 2), with greater decreases in abundance in Amphibolis meadows than in Posidonia meadows. Bittium spp. also decreased in abundance with increasing distance (Fig. 1C), but the pattern was less widespread than for Phasianella spp., with higher abundances at 0 and $10 \mathrm{~m}$ than at $>300$ for 10 and 5 of the pairwise comparisons, respectively.

In contrast, several taxa increased in abundance with increasing distance from reefs (Cantharidus lepidus, Fig. 1E; Thalotia chlorostoma, Fig. 1F). Abundances were higher in seagrass interiors $(>300 \mathrm{~m})$ than in seagrasses immediately adjacent to reefs $(0 \mathrm{~m})$ for 14 and 12 of the pairwise comparisons, respectively, for $C$. lepidus and T. chlorostoma. Abundances in seagrasses at $>300 \mathrm{~m}$ away from reefs were higher than at $10 \mathrm{~m}$ for 12 and 10 pairwise comparisons, respectively, for C. lepidus and $T$. chlorostoma. Dentimitrella spp. (Fig. 1D) and Hydrobidae (Fig. 1H) showed inconsistent patterns in seagrasses with decreasing proximity to reefs ('Reef [Location $\times$ Seagrass] $\times$ Distance', $\mathrm{p}<$ 0.01 ; Tables $1 \& 2$ ), although these taxa were, in general, more abundant on reefs than in seagrass meadows (Fig. 1D, $\mathrm{H}_{i}$ 'Distance', $\mathrm{p}<0.05$ in most cases; Tables 1 \& 2). Similarly, Prothalotia lehmanni did not display consistent patterns with proximity to reefs (Fig. 1G).

In general, patterns of distribution of gastropods in seagrasses with varying proximity to reefs were consistent in sign between Posidonia and Amphibolis seagrass meadows ('Seagrass $\times$ Distance', p > 0.05; Tables 1 \& 2) highlighting the generality of our findings across 2 different seagrass habitats. None of these responses was confounded by differences in several

Table 1. ANCOVA (F-ratios) testing the effects of 'Location' (Lo), 'Seagrass' (Sg), 'Reef' and 'Distance' (Di) on the abundance of the 8 most abundant gastropod species for austral summer/autumn 2006. In all cases, Cochran's $C$-tests were significant (p < 0.01), except that for Thalotia chlorostoma. ${ }^{* *} \mathrm{p}<0.01,{ }^{*} 0.01<\mathrm{p}<0.05$

\begin{tabular}{|c|c|c|c|c|c|c|c|c|c|c|}
\hline & $\begin{array}{c}\text { MS denominator } \\
\text { term }\end{array}$ & $\mathrm{df}$ & $\begin{array}{c}\text { Pyrene } \\
\text { bidentata }\end{array}$ & $\begin{array}{l}\text { Phasianella } \\
\text { spp. }\end{array}$ & $\begin{array}{l}\text { Bittium } \\
\text { spp. }\end{array}$ & $\begin{array}{c}\text { Cantharidus } \\
\text { lepidus }\end{array}$ & $\begin{array}{l}\text { Thalotia } \\
\text { chlorostoma }\end{array}$ & $\begin{array}{l}\text { Dentimi- } \\
\text { trella spp. }\end{array}$ & $\begin{array}{l}\text { Hydro- } \\
\text { bidae }\end{array}$ & $\begin{array}{c}\text { Prothalotia } \\
\text { lehmanni }\end{array}$ \\
\hline Vegetation biomass & & 1 & $47.46^{* *}$ & $14.40^{*}$ & 0.04 & $15.83^{*}$ & 0.86 & 0.32 & $7.43^{*}$ & $92.88^{* *}$ \\
\hline Location & Reef (Lo × Sg) & 1 & 1.76 & $8.28^{*}$ & 0.64 & 0.007 & 0.28 & 1.78 & 0.06 & 0.49 \\
\hline Seagrass & Reef $(\mathrm{Lo} \times \mathrm{Sg})$ & 1 & 1.79 & 2.7 & 3.4 & 0.99 & 47.82 & 32.99 & 0.58 & 8.17 \\
\hline Reef $(\mathrm{Lo} \times \mathrm{Sg})$ & Residual & 8 & $10.27^{* *}$ & $17.02^{* *}$ & $2.42^{* *}$ & $6.14^{* *}$ & $4.34^{* *}$ & $3.43^{* *}$ & $17.65^{* *}$ & $8.58^{* *}$ \\
\hline Distance & Reef $(\mathrm{Lo} \times \mathrm{Sg}) \times \mathrm{Di}$ & 4 & $23.84^{* *}$ & $8.94^{*}$ & $4.023^{* *}$ & $17.70^{* *}$ & $8.24^{*}$ & 2.63 & 3.29 & 0.2 \\
\hline $\mathrm{Lo} \times \mathrm{Sg}$ & Reef $(\mathrm{Lo} \times \mathrm{Sg})$ & 1 & 5.36 & 2.59 & 0.4 & 1.33 & 0.001 & 0.004 & 0.03 & 0.43 \\
\hline $\mathrm{Lo} \times \mathrm{Di}$ & Reef $(\mathrm{Lo} \times \mathrm{Sg}) \times \mathrm{Di}$ & 4 & 0.66 & $3.71^{*}$ & 1.56 & 0.81 & 0.54 & 1.44 & 0.9 & 1.43 \\
\hline $\mathrm{Sg} \times \mathrm{Di}$ & Reef $(\mathrm{Lo} \times \mathrm{Sg}) \times \mathrm{Di}$ & 4 & 3.59 & 2.83 & 0.81 & 0.18 & 0.14 & 0.94 & 0.67 & 0.48 \\
\hline Reef $(\mathrm{Lo} \times \mathrm{Sg}) \times \mathrm{Di}$ & Residual & 32 & $3.28^{* *}$ & $2.14^{* *}$ & $2.30^{* *}$ & $2.99^{* *}$ & $3.04^{* *}$ & $3.77^{* *}$ & $3.69^{* *}$ & $1.69^{* *}$ \\
\hline $\mathrm{Lo} \times \mathrm{Sg} \times \mathrm{Di}$ & Reef $(\mathrm{Lo} \times \mathrm{Sg}) \times \mathrm{Di}$ & 4 & 0.76 & 2.12 & 1.37 & $5.10^{*}$ & $4.49^{*}$ & 0.08 & 1.06 & $3.49^{*}$ \\
\hline
\end{tabular}

Table 2. ANCOVA (F-ratios) testing the effects of 'Location' (Lo), 'Seagrass' (Sg), 'Reef' and 'Distance' (Di) on the abundance of the 8 most abundant gastropod species for austral summer/autumn 2007. In all cases, Cochran's $C$-tests were significant ( $p<0.01)$. ${ }^{* *} \mathrm{p}<0.01$, ${ }^{*} 0.01<\mathrm{p}<0.05$

\begin{tabular}{|c|c|c|c|c|c|c|c|c|c|c|}
\hline & $\begin{array}{c}\text { MS denominator } \\
\text { term }\end{array}$ & $\mathrm{df}$ & $\begin{array}{l}\text { Pyrene } \\
\text { bidentata }\end{array}$ & $\begin{array}{l}\text { Phasianella } \\
\text { spp. }\end{array}$ & $\begin{array}{l}\text { Bittium } \\
\text { spp. }\end{array}$ & $\begin{array}{c}\text { Cantharidus } \\
\text { lepidus }\end{array}$ & $\begin{array}{l}\text { Thalotia } \\
\text { chlorostoma }\end{array}$ & $\begin{array}{l}\text { Dentimi- } \\
\text { trella spp. }\end{array}$ & $\begin{array}{l}\text { Hydro- } \\
\text { bidae }\end{array}$ & $\begin{array}{r}\text { Prothalotia } \\
\text { lehmanni }\end{array}$ \\
\hline Vegetation biomass & & 1 & $5.12^{*}$ & $5.97^{*}$ & 0.19 & 1.73 & $25.24^{* *}$ & 1.24 & 2.46 & $117.26^{* *}$ \\
\hline Location & Reef $(\mathrm{Lo} \times \mathrm{Sg})$ & 1 & 0.69 & 2.64 & 0.13 & 0.04 & 0.02 & 0.92 & 0.19 & 0.43 \\
\hline Seagrass & Reef $(\mathrm{Lo} \times \mathrm{Sg})$ & 1 & 0.67 & 35.5 & 36.51 & 1.69 & 2.37 & 12.33 & 0.28 & 2.38 \\
\hline Reef $(\mathrm{Lo} \times \mathrm{Sg})$ & Residual & 8 & $23.38^{* *}$ & $5.46^{* *}$ & $2.81^{* *}$ & $5.42^{* *}$ & $5.95^{* *}$ & $2.77^{* *}$ & $14.07^{* *}$ & $6.40^{* *}$ \\
\hline Distance & Reef $(\mathrm{Lo} \times \mathrm{Sg}) \times \mathrm{Di}$ & 4 & $26.79^{* *}$ & $17.18^{* *}$ & $3.04^{*}$ & $40.17^{* *}$ & 426.58 & $18.01^{*}$ & $3.27^{*}$ & 10.38 \\
\hline Lo $\times \mathrm{Sg}$ & Reef $(\mathrm{Lo} \times \mathrm{Sg})$ & 1 & 0.86 & 0.3 & 0.002 & 0.19 & 0.83 & 0.06 & 0.67 & 0.89 \\
\hline Lo $\times \mathrm{Di}$ & Reef $(\mathrm{Lo} \times \mathrm{Sg}) \times \mathrm{Di}$ & 4 & 0.59 & 1.76 & 1.21 & 0.27 & 0.01 & 0.54 & 0.83 & 0.06 \\
\hline $\mathrm{Sg} \times \mathrm{Di}$ & Reef $($ Lo $\times \mathrm{Sg}) \times \mathrm{Di}$ & 4 & 0.82 & $29.94^{* *}$ & 1.54 & 0.78 & 2.38 & 0.87 & 1.67 & 1.81 \\
\hline Reef $(\mathrm{Lo} \times \mathrm{Sg}) \times \mathrm{Di}$ & Residual & 32 & $5.62^{* *}$ & $2.55^{* *}$ & $2.28^{* *}$ & $1.63^{* *}$ & $4.60^{* *}$ & $2.87^{* *}$ & $8.20^{* *}$ & $2.27^{* *}$ \\
\hline $\mathrm{Lo} \times \mathrm{Sg} \times \mathrm{Di}$ & Reef $(\operatorname{Lo} \times \mathrm{Sg}) \times \mathrm{Di}$ & 4 & 1.1 & 0.68 & 0.93 & 1.24 & 1.4 & 0.08 & 0.38 & 0.53 \\
\hline Residual & & 239 & & & & & & & & \\
\hline
\end{tabular}


structural elements of each seagrass species that did not vary with proximity to reefs ('Distance', $p>0.10$ in all cases; Tables S2 \& S3 in the supplement). Since the biomass of each seagrass species was then irrespective of proximity to reefs, the assumption of independence of the covariate (vegetation biomass) and the treatment effects was valid.

\section{Distribution of predators}

Predatory fish were, in general, more abundant on reefs than in adjacent seagrass meadows (Fig. 2), although the magnitude of these differences varied from reef to reef ('Reef [Location $\times$ Seagrass] $\times$ Distance', p $<0.01$; Table 3). In most cases, fish abun-

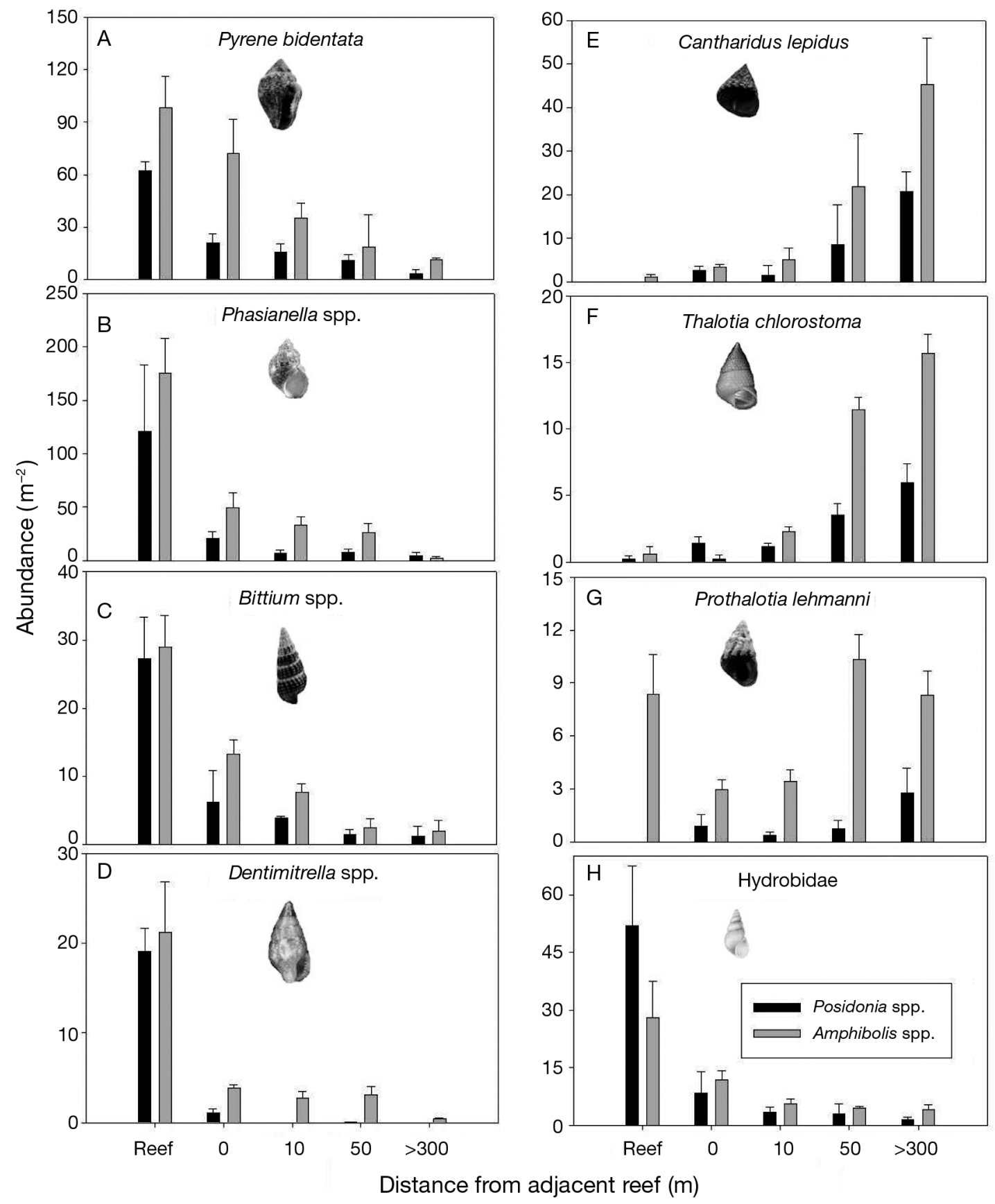

Fig. 1. Abundances (mean $+\mathrm{SE}, \mathrm{n}=60$ ) of gastropods on reefs and at various distances in adjacent seagrass meadows dominated by either Amphibolis or Posidonia (data pooled through all random variability: locations, reefs within each location and surveys) 

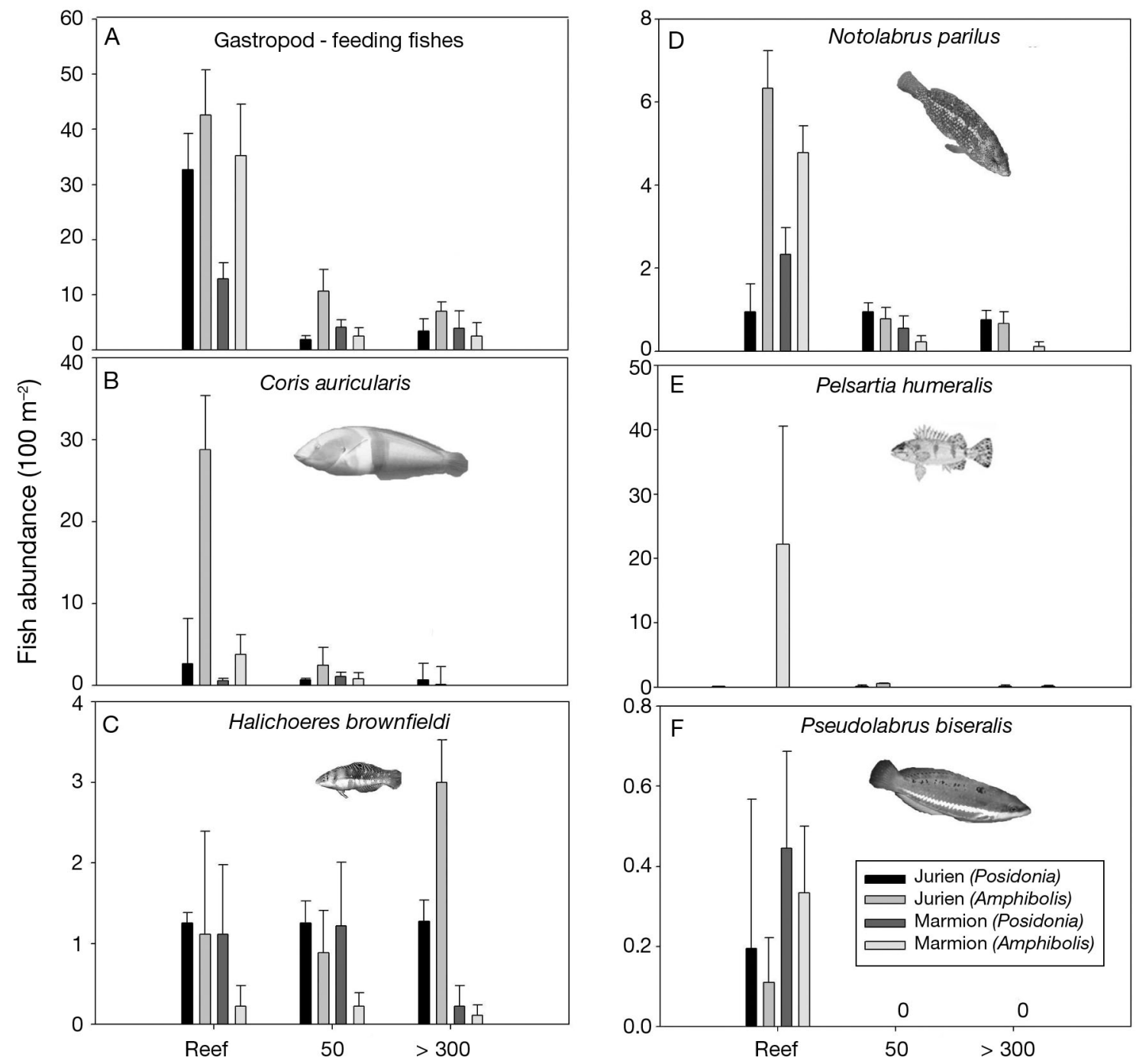

Distance from adjacent reef $(\mathrm{m})$

Fig. 2. Abundances (mean $+\mathrm{SE}, \mathrm{n}=9$ ) of predatory fishes on reefs and at various distances in adjacent seagrass meadows dominated by either Amphibolis or Posidonia (data pooled through all random variability: locations and reefs within each location)

Table 3. Results of ANOVA (F-ratios) testing the effects of 'Location' (Lo), 'Seagrass' (Sg), 'Reef' and 'Distance' (Di) on the abundance of predatory fishes. ${ }^{* *} \mathrm{p}<0.01,{ }^{*} 0.01<\mathrm{p}<0.05$

\begin{tabular}{|c|c|c|c|c|c|c|c|c|}
\hline & df & $\begin{array}{l}\text { MS denominator } \\
\text { term }\end{array}$ & $\begin{array}{l}\text { Predatory } \\
\text { fishes }\end{array}$ & $\begin{array}{l}\text { Coris } \\
\text { auricularis }\end{array}$ & $\begin{array}{r}\text { Halichoeres } \\
\text { brownfieldi }\end{array}$ & $\begin{array}{l}\text { Notolabrus } \\
\text { parilus }\end{array}$ & $\begin{array}{l}\text { Pelsartia } \\
\text { humeralis }\end{array}$ & $\begin{array}{l}\text { Pseudolabrus } \\
\text { biseralis }\end{array}$ \\
\hline Location & 1 & Reef $(\mathrm{Lo} \times \mathrm{Sg})$ & $7.87^{*}$ & $8.22^{* *}$ & 4.34 & 4.46 & 0.65 & 0 \\
\hline Seagrass & 1 & Reef $(\mathrm{Lo} \times \mathrm{Sg})$ & 0.08 & 0.36 & 0.25 & $12.39^{*}$ & 6.18 & 0.64 \\
\hline Reef $(\mathrm{Lo} \times \mathrm{Sg})$ & 8 & Residual & $3.43^{* *}$ & $8.98^{* *}$ & 1.08 & 1.43 & 0.4 & $8.00^{* *}$ \\
\hline Distance & 2 & Reef $(\mathrm{Lo} \times \mathrm{Sg}) \times \mathrm{Di}$ & $66.80^{* *}$ & $13.47^{* *}$ & 1.69 & $67.46^{* *}$ & 1 & $3.50^{*}$ \\
\hline $\mathrm{Lo} \times \mathrm{Sg}$ & 1 & Reef $(\mathrm{Lo} \times \mathrm{Sg})$ & 2.19 & 0.07 & 0.62 & 0.92 & 0.18 & 0.28 \\
\hline $\mathrm{Lo} \times \mathrm{Di}$ & 2 & Reef $(\mathrm{Lo} \times \mathrm{Sg}) \times \mathrm{Di}$ & 1.62 & $10.29^{* *}$ & $4.35^{*}$ & 1.18 & 1.17 & 0 \\
\hline $\mathrm{Sg} \times \mathrm{Di}$ & 2 & Reef $(\mathrm{Lo} \times \mathrm{Sg}) \times \mathrm{Di}$ & 7.04 & 0.24 & 0.37 & $7.51^{* *}$ & 0.67 & 0.64 \\
\hline Reef $(\mathrm{Lo} \times \mathrm{Sg}) \times \mathrm{Di}$ & 16 & Residual & $2.04^{*}$ & $6.84^{* *}$ & 0.74 & 1.66 & 1 & $8.00^{* *}$ \\
\hline $\mathrm{Lo} \times \mathrm{Sg} \times \mathrm{Di}$ & 2 & Reef $(\mathrm{Lo} \times \mathrm{Sg}) \times \mathrm{Di}$ & 0.08 & 0.02 & 0.4 & 0.04 & 1.41 & 0.28 \\
\hline Residual & 72 & & & & & & & \\
\hline
\end{tabular}


dance was higher on reefs relative to seagrass meadows at both distances surveyed (i.e. both 50 and $>300 \mathrm{~m}$ distances, Table S4). Halichoeres brownfieldi

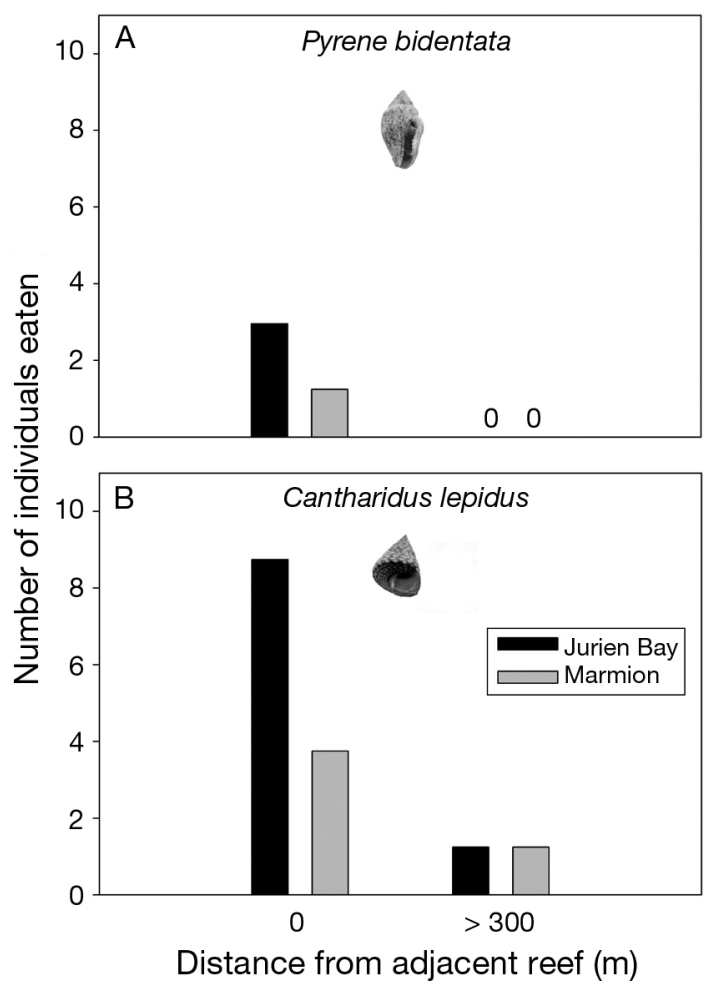

Fig. 3. Relative intensity of predation (number of tethered gastropods eaten during 5 days, $\mathrm{n}=20$ ) on $P$. bidentata and $C$. lepidus in seagrass meadows at various distances from adjacent reefs

Table 4. Results of logistic regression testing for differences in survival of tethered gastropods. All lower-level interactions were highly nonsignificant $(p>0.8)$

\begin{tabular}{|lccc|}
\hline Source of variation & df & Deviance & $\mathrm{p}$ \\
\hline Species (Sp, Pyrene bidentata vs. & 1 & 6.34 & 0.012 \\
$\quad$ Cantharidus lepidus) & & & \\
Seagrass (Sg) & 1 & 0.08 & 0.782 \\
$\mathrm{Sp} \times \mathrm{Sg}$ & 1 & 0.28 & 0.599 \\
$\mathrm{Location}(\mathrm{Lo})$ & 1 & 1.94 & 0.163 \\
$\mathrm{Sp} \times \mathrm{Lo}$ & 1 & 0.004 & 0.950 \\
$\mathrm{Sg} \times \mathrm{Lo}$ & 1 & 2.60 & 0.107 \\
$\mathrm{Sp} \times \mathrm{Sg} \times \mathrm{Lo}$ & 1 & 0.25 & 0.619 \\
$\mathrm{Reef}(\mathrm{Sg} \times \mathrm{Lo})$ & 4 & 6.29 & 0.178 \\
$\mathrm{Sp} \times \mathrm{Reef}(\mathrm{Sg} \times \mathrm{Lo})$ & 4 & 7.08 & 0.132 \\
$\mathrm{Distance}(\mathrm{Di})$ & 1 & 11.65 & 0.0006 \\
$\mathrm{Sp} \times \mathrm{Di}$ & 1 & 0.71 & 0.400 \\
$\mathrm{Sg} \times \mathrm{Di}$ & 1 & 4.47 & 0.034 \\
$\mathrm{Lo} \times \mathrm{Di}$ & 1 & 0.006 & 0.938 \\
Residual & 128 & 56.86 & 1.000 \\
& & & \\
\hline
\end{tabular}

was the only exception to this general pattern (Fig. 2C), being equally abundant on reefs and in seagrass meadows. Pelsartia humeralis was only present in appreciable numbers at one reef (Fig. 2E; 'Distance', p > 0.2; Table 3). Abundance of Notolabrus parilus decreased with increasing distance from reefs, but the decrease was more pronounced in Amphibolis meadows (Fig. 2D; 'Seagrass $\times$ Distance', $\mathrm{p}<0.01$; Table 3), due to the higher abundance of this species on reefs bordering Amphibolis meadows. On the whole, the total abundance of predatory fishes was greater at Jurien Bay compared with Marmion; this pattern was primarily driven by Coris auricularis, the most abundant predatory fish overall (Fig. 2A,B, respectively; 'Location', $\mathrm{p}<0.05$; Table 3). Similarly, rock lobsters were more abundant in Jurien Bay $\left(1.54 \pm 0.23\right.$ individuals [ind.] $100 \mathrm{~m}^{-2}$, mean $\left.\pm \mathrm{SE}\right)$ relative to Marmion, where no individuals were observed in the transects.

\section{Predation on gastropods}

Predation intensity on tethered gastropods was greater in seagrasses at $0 \mathrm{~m}$ than at $>300 \mathrm{~m}$ away from reefs for both species of gastropods (Fig. 3A,B; 'Distance', p < 0.01; Table 4), with an odds ratio of 7.6 (i.e. tethered gastropods were 7.6 times more likely to be consumed at $0 \mathrm{~m}$ than at $>300 \mathrm{~m}$ ). Predation on Cantharidus lepidus (Fig. 3B) was higher than on Pyrene bidentata (Fig. 3A) ('Species', p < 0.01; Table 4), with an odds ratio of 4.5 (C. lepidus was 4.5 times more likely to be consumed than $P$. bidentata). This was reflected in the laboratory experiments, in which $C$. lepidus was 4.7 times more likely to be consumed than was $P$. bidentata by rock lobsters $(\mathrm{df}=1$, Deviance $=$ $16.08, \mathrm{p}<0.001$ ), though variation in predation by individual lobsters was evident $(\mathrm{df}=5$, Deviance $=33.17$, $\mathrm{p}<0.001)$.

\section{Recruitment of gastropods}

Abundance of recruits of Pyrene bidentata in ASUs was higher in seagrasses at $0 \mathrm{~m}$ than at $>300 \mathrm{~m}$ away from reefs (Fig. 4A; 'Distance', p < 0.01; Table 5), with $\sim 90 \%$ of individuals in the size range of 2 to $4 \mathrm{~mm}$ (Fig. 4A inset). In contrast, the abundance of recruits of Cantharidus lepidus (all individuals were 2 to $4 \mathrm{~mm}$, Fig. 4B inset) did not show consistent differences with distance from reefs (Fig. 4B; 'Distance', p > 0.1; Table 5), but showed inconsistent patterns from reef to reef ('Reef [Seagrass] $\times$ Distance', p < 0.01; Table 5; pairwise comparisons indicated greater abundance far away from reefs at only one reef). 


\section{DISCUSSION}

The present study demonstrates that ecological processes near habitat margins where seagrasses and reefs are juxtaposed can strongly influence the patterns of abundance of seagrass fauna. We documented a shift in the intensity of, and in the balance between, positive (recruitment) and negative (predation) effects on abundance from reef-seagrass edges to seagrass interiors. The balance was different between 2 gastropod species, and culminated in contrasting distributions with increasing distance from habitat edges. Importantly, the patterns in abundance that are the outcome of these competing processes were consistent in the 2 years that surveys were conducted. Most of these results, nonetheless, were obtained in just one season (austral summer/autumn), so we cannot rule

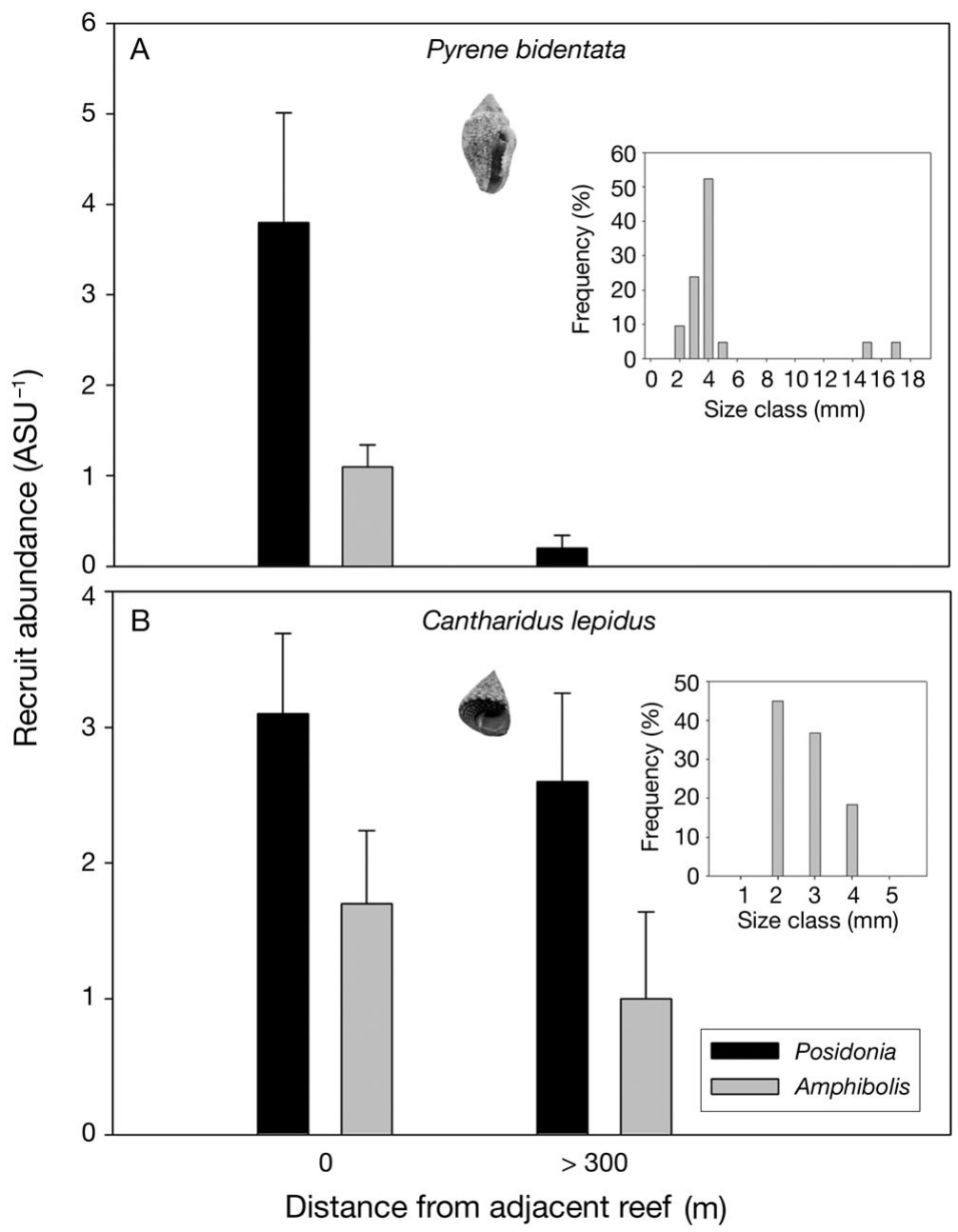

Fig. 4. Abundances (mean $+\mathrm{SE}, \mathrm{n}=10$ ) of recruits of Pyrene bidentata and Cantharidus lepidus in artificial seaweed units (ASUs) placed in seagrass meadows at various distances from adjacent reefs dominated by either Amphibolis or Posidonia. Insets: size-class distributions (total body whorl); data pooled through reefs (random variability) as well as from the 2 types of seagrass meadows as this factor was nonsignificant (Table 5)
Table 5. Results of ANOVA (F-ratios) testing the effects of 'Seagrass' (Sg), 'Reef' and 'Distance' (Di) on the abundance of recruits of gastropods in artificial seaweed units. Data were $\ln (x+1)$ transformed. ${ }^{* *} \mathrm{p}<0.01,{ }^{*} 0.01<\mathrm{p}<0.05$

\begin{tabular}{|c|c|c|c|c|}
\hline & df & $\begin{array}{c}\text { MS denominator } \\
\text { term }\end{array}$ & $\begin{array}{l}\text { r Pyrene } \\
\text { bidentata }\end{array}$ & $\begin{array}{l}\text { Cantharidus } \\
\text { lepidus }\end{array}$ \\
\hline Seagrass & 1 & Reef (Sg) & 18.94 & 8.44 \\
\hline Reef (Sg) & 2 & Residual & 0.21 & $4.21^{*}$ \\
\hline Distance & 1 & Reef $(\mathrm{Sg}) \times \mathrm{Di}$ & $130.26^{* *}$ & 0.15 \\
\hline $\mathrm{Sg} \times \mathrm{Di}$ & 1 & Reef $(\mathrm{Sg}) \times \mathrm{Di}$ & $20.57^{*}$ & 0.33 \\
\hline Reef $(\mathrm{Sg}) \times \mathrm{Di}$ & 2 & Residual & 0.21 & $8.50^{* *}$ \\
\hline Residual & 32 & & & \\
\hline
\end{tabular}

out that some of these outcomes can change over large time scales. Moreover, our experimental measurements (predation and recruitment patterns) were, due to logistical constraints, limited to the endpoints of the reef-seagrass landscape, so we cannot unambiguously leave out other potential factors that can affect these processes along reef-seagrass landscapes.

\section{Proximity to reefs influences predator abundances and predation rates}

Predatory fish were considerably more abundant on reefs than in seagrass meadows away from reefs, reflecting the global generality of this pattern for carnivorous fishes where reefs and seagrasses are adjacent (Dorenbosch et al. 2005, Vanderklift et al. 2007, Valentine et al. 2008). In addition to fishes, the western rock lobster Panulirus cygnus moves from reefs to adjacent seagrass meadows during the night to forage (Edgar 1990a,b), typically within $\sim 50 \mathrm{~m}$ of the reef edge (MacArthur et al. 2008). This concentration of predators near reefs matched the spatial patterns in predation intensity on both species of gastropods used in the tethering experiments. The higher predation detected at Jurien Bay is also consistent with the higher abundance of predators (fishes and rock lobsters) at this location.

The higher abundance of predatory fishes in seagrasses adjacent to reefs, regardless of the dominant seagrass species, is similar to the finding of previous studies using similar visual techniques in the study area (Wernberg et al. 2006, 
Vanderklift et al. 2007), although this outcome might differ if other techniques were implemented, because visual counts underestimate cryptic species (Hyndes et al. 2003). The spatial correspondence between abundance of predators and rates of predation on tethered prey suggests that cryptic predators are probably not important predators of gastropods. However, it is also possible that other cryptic predators, such as octopuses and other molluscs, help drive the observed abundance patterns by foraging at a higher intensity closer to reefs.

Predation by reef-associated predators may also explain gradients in abundance of fauna in soft bottoms adjacent to reefs (Langlois et al. 2005, Galvan et al. 2008). Similarly, higher predation in seagrass meadows immediately adjacent to reefs was probably due to the greater densities of predators (fishes and rock lobsters) on and near reefs. These results demonstrate the importance of proximity to edges not only for predator abundance, but also as a key influence on the strength of predation (Rand et al. 2006).

\section{Prey identity influences predation intensity}

The intensity of predation, and its effect on prey abundance, varied considerably between prey species. Selection of molluscan prey depends, among other factors, on prey morphology, which influences a predator's handling time (Seitz et al. 2001). The vulnerability of gastropods to shell-crushing predation by crustaceans decreases with an increase in shell wall thickness (Robles et al. 1990). In our study, Cantharidus lepidus was more frequently consumed in field and laboratory experiments than was Pyrene bidentata; in turn, because of its comparatively thin shell (Edgar 1990b), C. lepidus is one of the main gastropod prey of western rock lobsters in the study area (MacArthur et al. 2006). In contrast, rock lobsters have great difficulty breaking through the thicker shell of $P$. bidentata (Edgar 1990b), which was confirmed in our laboratory experiments. Indeed, adult $P$. bidentata have low rates of mortality and survive for several years (Edgar $1990 a, b)$. At the moment, we cannot differentiate between the effects of predation by rock lobsters and fishes. However, it is also likely that the vulnerability of $C$. lepidus to fish predation is greater relative to that for $P$. bidentata, since fish have similar difficulties with thick-shelled prey (Palmer 1979).

\section{Proximity to reefs influences the supply of recruits}

Proximity to sources of recruits influences patterns in composition and abundance of biota (Witman \& Day- ton 2001). For example, proximity to reefs affects the epiphytes colonizing adjacent seagrass meadows (Van Elven et al. 2004). Artificial substrata are mainly colonized through recruitment of planktonic larvae or migration (e.g. drifting, crawling) of juveniles and adults from nearby habitats (Rule \& Smith 2007). The prevailing mechanism depends on the larval ecology of each species. Most individuals of both Pyrene bidentata and Cantharidus lepidus collected in the ASUs were uniformly small, and thus were probably new recruits from the same cohort.

The larval ecology of Pyrene bidentata is unknown; however, larvae of pyrenid gastropods are typically nonplanktonic, developing within egg masses until they emerge as crawling juveniles (Amio 1955, Wilson 1993). P. bidentata can easily colonize artificial seaweed units several meters away from adjacent algal patches (Tuya et al. 2009). Dispersion of individuals from either the reef or the surrounding seagrass, both of which hosted greater abundance of $P$. bidentata than seagrass interiors, therefore probably explains the greater recruitment of $P$. bidentata at seagrass edges relative to interiors. In contrast, abundance of recruits of Cantharidus lepidus, which were not abundant on or near reefs (Tuya et al. 2008, present study), varied little in seagrasses with proximity to reefs. Most Australasian trochid gastropods have a short planktonic larval stage (Wilson 1993), typically 1 wk (Edgar 2000). The spatial extent over which larvae of $C$. lepidus can disperse is thus probably greater than $P$. bidentata, a trait that probably explains the invariance of $C$. lepidus recruit abundance with proximity to reefs.

\section{Minor effects of seagrass species on patterns and processes with proximity to reefs}

The physiognomy of seagrasses can interact with different factors (e.g. predation, competition) to alter ecological patterns and the magnitude of ecological processes (Hemminga \& Duarte 2000, Heck \& Orth 2006). However, patterns and processes in seagrasses with proximity to reefs were, in general, consistent in direction (although for some variables varied in magnitude) between Posidonia and Amphibolis seagrass meadows, highlighting the generality of our findings across 2 types of seagrass habitats. Moreover, significant changes in the density of both seagrass species with varying proximity to reefs were not detected, so we can rule out the potential confounding effect of seagrass habitat structure on the patterns and processes outlined by the present study on seagrass with varying proximity to reefs.

High predation of tethered gastropods occurred in seagrasses near reefs for both Posidonia and Amphibolis meadows, although the magnitude of predation was 
different. This outcome is similar to the consumption of crabs (Vanderklift et al. 2007) and detached kelp (Wernberg et al. 2006) in both seagrasses with varying proximity to reefs in the study area. Therefore, these results suggest a lack of interactive effects between proximity to reefs and the dominant species of seagrass as determinants of the intensity of these 'top-down' processes.

\section{Balance between positive and negative influences depends on proximity to reefs and species identity}

Dispersal of individuals of Pyrene bidentata from either reefs or surrounding seagrass probably explains the greater recruitment of $P$. bidentata at seagrass margins relative to interiors. This may compensate for losses due to predation, facilitating high abundance in seagrasses adjacent to reefs despite higher predation here versus in seagrass meadow interiors. In contrast, predation considerably reduced the abundance of Cantharidus lepidus in seagrasses adjacent to reefs, while reefs did not affect recruitment patterns, so that this species was more abundant in seagrass meadow interiors.

Historically, small herbivorous gastropods have been often considered as a homogeneous functional group in marine habitats, such as seagrass meadows; however, the relevance of species identity in the functioning of seagrass ecosystems is increasingly recognized (Duffy et al. 2001). Our study supports the notion that species identity does matter not only for the functioning of seagrass ecosystems, but it also strongly influences the patterns of abundance and distribution that emerge from the various competing processes. We documented that the intensity of linkages between seagrass meadows and reefs depends on proximity, but also is strongly connected with the identities of predators and prey. As a result, generalizations concerning the relative importance of different ecological processes, even within the same assemblage, are therefore dependent on the identities of the species, as has been reported from tropical coral reefs (Burkepile \& Hay 2008). A challenge for ecologists is to quantify the traits that enable species to flourish in different circumstances.

In summary, proximity to habitat margins influenced abundance and distribution patterns of herbivorous fauna by changing the balance of forces influencing the mortality (predation) and the replenishment (recruitment) of these populations from habitat edges to interiors.

Acknowledgements. F.T. was supported by a postdoctoral research fellowship within the MEC framework Plan de Formación y Perfeccionamiento. This work was funded by an ECU Faculty Small Grant and the Strategic Research Fund for the Marine Environment. The Western Australia Department of Fisheries kindly enabled access to an indoor tanks facility. We thank A. Abelardo, N. Alcorriz, C. Doropoulus, A. Gartner, P. Lavery and B. Toohey for their help during the field work. P. Lavery, T. Langlois, L. MacArthur and 4 anonymous reviewers provided constructive comments on previous drafts of the manuscript. The work detailed in this paper complies with the laws of Australia.

\section{LITERATURE CITED}

Amio M (1955) On the eggs and early life histories of Pyrenidae (Columbellidae) in marine gastropods. J Shimonoseki Collect Fish 4:231-238

Bell SS, McCoy ED, Mushinsky HR (eds) (1991) Habitat structure: the physical arrangement of objects in space. Chapman \& Hall, London

Burkepile DE, Hay ME (2008) Herbivore species richness and feeding complementarity affect community structure and function on a coral reef. Proc Natl Acad Sci USA 105: 16201-16206

Cadenasso ML, Pickett STA, Weathers KC, Jones CG (2003) A framework for a theory of ecological boundaries. BioScience 53:750-758

> Dorenbosch M, Grol MGG, Christianen MJA, Nagelkerken I, van der Velde G (2005) Distribution of coral reef fishes along coral reef-seagrass gradient: edge effects and habitat segregation. Mar Ecol Prog Ser 299:277-288

Duffy JE, MacDonald KS, Rhode JM, Parker JD (2001) Grazer diversity, functional redundancy, and productivity in seagrass beds: an experimental test. Ecology 82:2417-2434

Edgar GJ (1990a) Predator-prey interactions in seagrass beds. I. The influence of macrofaunal abundance and sizestructure on the diet and growth of the western rock lobster Panulirus cygnus George. J Exp Mar Biol Ecol 139: $1-22$

Edgar GJ (1990b) Predator-prey interactions in seagrass beds. III. Impacts of the western rock lobster Panulirus cygnus George on epifaunal gastropod populations. J Exp Mar Biol Ecol 139:33-42

Edgar GJ (2000) Australian marine life: the plants and animals of temperate waters. New Holland Publishers, Sydney

Eggleston DB, Elis WE, Etherington LL, Dahlgren CP, Posey MH (1999) Organism response to habitat patchiness and diversity: habitat colonization by estuarine macrofauna. J Exp Mar Biol Ecol 236:107-132

Fagan WF, Cantrell RS, Cosner C (1999) How habitat edges change species interactions. Am Nat 153:165-182

Galvan DE, Parma AM, Iribarne OO (2008) Influence of predatory reef fishes on the spatial distribution of Munida gregaria ( $=M$. subrugosa) (Crustacea; Galatheidae) in shallow Patagonian soft bottoms. J Exp Mar Biol Ecol 354: 93-100

Heck KL Jr, Crowder LB (1991) Habitat structure and predator-prey interaction in vegetated aquatic systems. In: Bell SS, McCoy ED, Mushinsky HR (eds) Habitat structure: the physical arrangement of objects in space. Chapman \& Hall, New York, p 281-299

Heck KL Jr, Orth RJ (2006) Predation in seagrass beds. In: Larkum AWD, Orth RJ, Duarte CM (eds) Seagrasses: biology, ecology and conservation. Springer, Dordrecht, p 537-550

Hemminga MA, Duarte CM (2000) Seagrass ecology. Cambridge University Press, Cambridge

Hosmer DW, Lemeshow S (2000) Applied logistic regression. John Wiley \& Sons, New York

Hyndes GA, Kendrick AJ, MacArthur LD, Stewart E (2003) 
Differences in the species- and size-composition of fish assemblages in three distinct seagrass habitats with differing plant and meadow structure. Mar Biol 142:1195-1206

Jernakoff P, Nielsen J (1998) Plant-animal associations in two species of seagrasses in Western Australia. Aquat Bot 60: 359-376

Kareiva P, Wennergren U (1995) Connecting landscape patterns to ecosystem and population processes. Nature 373 : 299-302

Langlois TJ, Anderson MJ, Babcock RC (2005) Reef-associated predators influence adjacent soft-sediment communities. Ecology 86:1508-1519

MacArthur LD, Hyndes GA (2007) Varying foraging strategies of Labridae in seagrass habitats: herbivory in temperate seagrass meadows? J Exp Mar Biol Ecol 340:247-258

MacArthur LD, Hyndes GA, Babcock RC, Vanderklift MA (2006) Ecological interactions in coastal marine ecosystems: rock lobster. In: Keesing JK, Heine JN (eds) Strategic fund for the marine environment. Final Report. Strategic Research Fund for the Marine Environment, CSIRO, Perth, Western Australia, p 143-154

MacArthur LD, Hyndes GA, Babcock RC, Vanderklift MA (2008) Nocturnally active western rock lobsters, Panulirus cygnus, forage close to shallow coastal reefs. Aquat Biol 4: 201-210

Menge BA (2000) Recruitment vs. postrecruitment processes as determinants of barnacle population abundance. Ecol Monogr 70:265-288

Palmer RA (1979) Fish predation and the evolution of gastropod shell sculpture: experimental and geographic evidence. Evolution 33:697-713

> Peterson CH, Black R (1994) An experimentalist's challenge: when artifacts of intervention interact with treatments. Mar Ecol Prog Ser 111:289-297

Pulliam HR (1988) Sources, sinks, and population regulation. Am Nat 132:652-661

Quensen JF III, Woodruff DS (1997) Associations between shell morphology and land crab predation in the land snail Cerion. Funct Ecol 11:464-471

Rand TA, Tylianakis JM, Tsacharntke T (2006) Spillover edge effects: the dispersal of agriculturally subsidized insect natural enemies into adjacent natural habitats. Ecol Lett 9: 603-614

Robles C, Sweetnam D, Eminike J (1990) Lobster predation on mussels: shore-level differences in prey vulnerability and predator preference. Ecology 71:1564-1577

Rodriguez A, Andren H, Jansson G (2001) Habitat-mediated

Editorial responsibility: Just Cebrian,

Dauphin Island, Alabama, USA predation risk and decision making of small birds at forest edges. Oikos 95:383-396

Rule MJ, Smith SDA (2007) Depth-associated patterns in the development of benthic assemblages on artificial substrata deployed on shallow, subtropical reefs. J Exp Mar Biol Ecol 345:38-51

Seitz RD, Lipcius RN, Hines AH, Eggleston DB (2001) Density-dependent predation: habitat variation, and the persistence of marine bivalve prey. Ecology 82:2435-2451

Tuya F, Wernberg T, Thomsen MS (2008) The spatial arrangement of reefs alters the ecological patterns of fauna between interspersed habitats. Estuar Coast Shelf Sci 78: 774-782

Tuya F, Wernberg T, Thomsen MS (2009) Colonization of gastropods on subtidal reefs depends on density in adjacent habitats, not disturbance regime or latitude. J Molluscan Stud 75:27-33

Underwood AJ (1997) Experiments in ecology: their logical design and interpretation using analysis of variance. Cambridge University Press, Cambridge

> Valentine JF, Heck KL Jr, Blackmon D, Goecker ME and others (2008) Impacts of exploited species on food web interactions along the coral reef-seagrass interface: a comparison using fished and no-take zones in the Florida Keys National Marine Sanctuary. Ecol Appl 18: 1501-1515

Van Elven BR, Lavery PS, Kendrick GA (2004) Reefs as contributors to diversity of epiphytic macroalgae assemblages in seagrass meadows. Mar Ecol Prog Ser 276:71-83

> Vanderklift MA, How J, Wernberg T, MacArthur LD, Heck KL Jr, Valentine JF (2007) Proximity to reef influences density of small predatory fishes, while type of seagrass influences intensity of their predation on crabs. Mar Ecol Prog Ser 340:235-243

Wernberg T, Kendrick GA, Phillips JC (2003) Regional differences in kelp-associated algal assemblages on temperate limestone reefs in south-western Australia. Divers Distrib 9:427-441

> Wernberg T, Vanderklift MA, How J, Lavery PS (2006) Export of detached macroalgae from reefs to adjacent seagrass beds. Oecologia 147:692-701

Wilson B (1993) Australian marine shells. Odyssey Publishing, Kallaroo

Witman JD, Dayton P (2001) Rocky subtidal communities. In: Bertness MD, Gaines SD, Hay ME (eds) Marine community ecology. Sinauer Associates, Sunderland, MA, p 329-336

Submitted: April 20, 2009; Accepted: January 27, 2010 Proofs received from author(s): April 26, 2010 